International Review of Research in Open and Distributed Learning Volume 21, Number 1

January - 2020

\title{
Designing a Community of Inquiry in Online Courses
} Holly S. Fiock

Purdue University, USA

\begin{abstract}
This article describes a practical approach for implementing instructional strategies in order to build a Community of Inquiry (CoI) into an online course. Online community building has positive effects on the quality of student learning, increases student engagement, and encourages motivation of students in online courses. The CoI is a theoretical framework focusing on facilitating meaningful learning experiences through three presences: cognitive presence, social presence, and teaching presence. This article will introduce the CoI framework by way of literature review focusing on CoI instructional strategies. Using Sorensen and Baylen's (2009) seven principles of good practice, the author will structure CoI instructional activities into presence categories for practitioner use.
\end{abstract}

Keywords: community of inquiry, online learning, instructional strategies, sense of community, collaborative learning, distance education 


\section{Introduction}

One of the most widely used frameworks for building communities online is the Community of Inquiry (CoI) theoretical framework developed by Garrison, Anderson, and Archer (2000). Applying the CoI framework as a lens, the purpose of this article is to provide a collection of CoI instructional strategies based in cognitive presence, social presence, and teaching presence (Garrison, Anderson, \& Archer, 2000), for practitioners (instructors, online course developers, instructional designers) to use in online courses. This collection of CoI instructional strategies is built using Sorensen and Baylen's (2009) seven principles of good practice. Garrison and Arbaugh (2007) indicated the need for practical strategies and guidelines for how to facilitate presence from a real-world pedagogical perspective as a future area for CoI research. This article hopes to fill this void.

\section{Community and Col Framework}

\section{History of Col}

Grounded in J ohn Dewey's (1938) view of practical inquiry, Garrison et al. first introduced the Community of Inquiry (CoI framework) in 2000 (as cited in Swan \&Ice, 2010). With inquiry and community at the core of his philosophy, Dewey believed individual development was dependent upon community (Swan, Garrison, \&Richardson, 2009). "Community," a word used copiously in educational research, is often used to refer to the cognitive or emotional connections established between physically separated learners. A broad construct of community has been defined by McMillan and Chavis (1986) as "a feeling that members have of belonging, a feeling that members matter to one another and to the group, and a shared faith that members' needs will be met through their commitment to be together" (p. 9). Wang, Laffey, and Poole (2001) argue that community can result from shared knowledge among online learners, and this online community is especially important as Rovai (2000) stated, "strong feelings of community increase the flow of information, the availability of support, commitment to group goals, cooperation among members, and satisfaction with group efforts" (p. 286).

\section{Col in Online Learning Environments}

The literature specifically advocates that within online environments, interaction between learners is of great importance to student success (Akyol \& Garrison, 2008; Arbaugh, 2008; Richardson, Maeda, Lv, \& Caskurlu, 2017). The CoI framework that highlights three core elements -cognitive presence, social presence, and teaching presence - is used to create a meaningful educational experience (Garrison et al., 2000). These presences are interdependent as depicted in Figure 1. The CoI framework assumes that effective online learning, particularly higher order learning, is dependent on the development of a community (Swan et al., 2009). Since its publication in 2000, researchers have suggested additions to the original framework in terms of presences, dimensions, and influences (Kozan \& Caskurlu, 2018; Peacock \& Cowan, 2016). This article will focus on three original presences as defined by Garrison et al. (2000). For additions to the CoI framework, refer to Kozan and Caskurlu (2018) and Peacock and Cowan (2016). The three presences of the CoI framerwork as discussed in this article are multidimensional, but in order to understand how they work collectively we must examine them individually. 


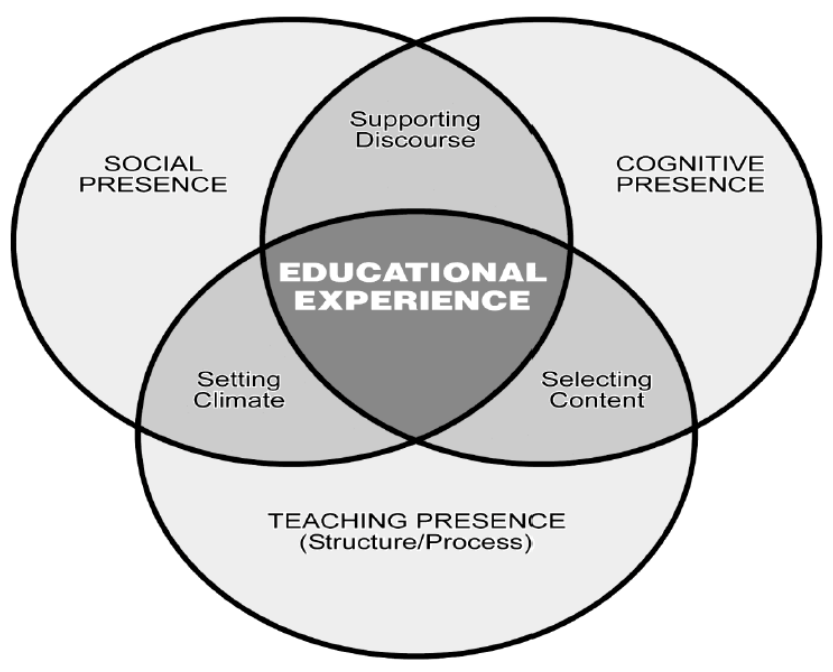

Figure 1. Community of inquiry framework. From "Critical Inquiry in a Text-Based Environment: Computer Conferencing in Higher Education," by D. R. Garrison, T. Anderson, and W. Archer, 2000, The Internet and Higher Education, 2, p. 88. Copyright 2000 by Elsevier Science Inc. Reprinted with permission.

\section{Cognitive Presence}

Cognitive presence, the ability to construct and confirm meaning through sustained reflection (Anderson, Rourke, Garrison, \& Archer, 2001), is demonstrated in the Practical Inquiry Model (PIM) created by Garrison et al. (2000) and depicted in Figure 2. The PIM includes four phases: (1) a triggering event, where a problem is identified for further inquiry; (2) exploration, where an individual explores the issue; (3) integration, where learners concept meaning from ideas formed in the exploration phase; and (4) resolution, where students can apply the new skills and knowledge learned from the previous phases into real-world application(s) (Garrison et al., 2000). Reflection is a key aspect of the CoI framework and helps learners to increase their cognitive presence as Redmond (2014) states, "reflecting on learning content and outcomes relates to knowledge acquisition where learners identify their increased knowledge and skills in the subject area" (p. 50). 


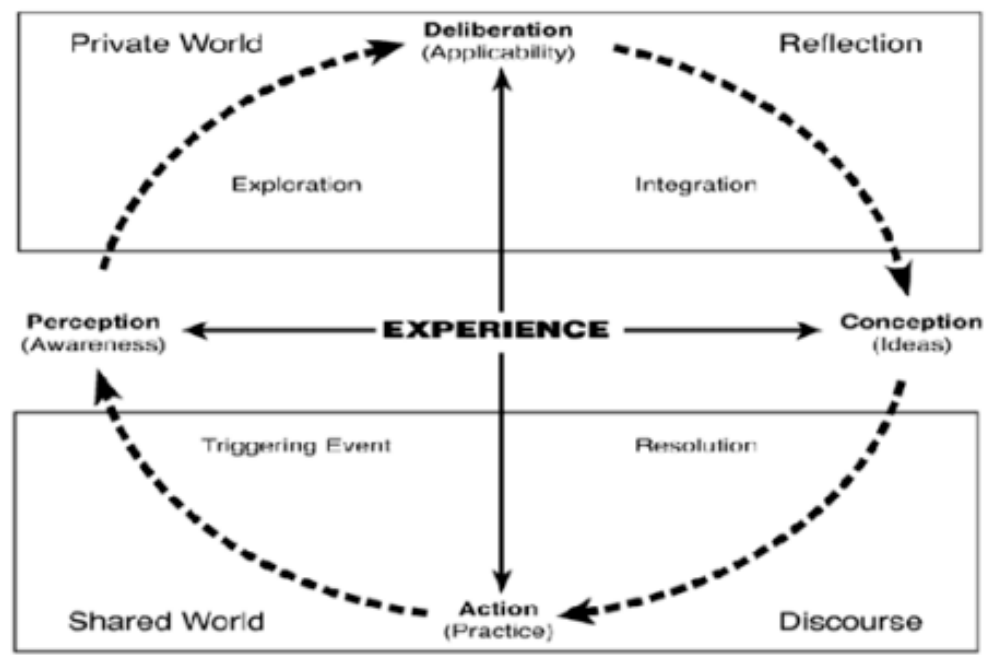

Figure 2. Practical inquiry model. From "Online Community of Inquiry Review: Social, Cognitive, and Teaching Presence Issues,” by D. R. Garrison, 2007, J ournal of Asynchronous Learning Networks, 11, p. 63. Copyright 2007 by ERIC. Reprinted with permission.

\section{Social Presence}

According to Lowenthal and Lowenthal (2010), "social presence is a theory that explains the ability of people to present themselves as 'real people' through a communication medium. Most studies on social presence focus on how students present themselves and/or are perceived as 'real' people online" (p. 1). Garrison et al. (2000) determined three categories of social presence indicators. These categories are: (1) emotional (affective) expression, where learners share personal expressions and values; (2) open communication, where learners develop aspects of mutual awareness and recognition; and (3) group cohesion, where learners build and sustain a sense of group commitment (Garrison et al., 2000). A study conducted by Richardson and Swan (2003) found that social presence positively affects student and instructor course satisfaction. During the study, a relationship between social presence and perceived learning was identified; students who perceived high social presence learned more than those who perceived low social presence (Richardson \& Swan, 2003).

\section{Teaching Presence}

Garrison and colleagues describe teaching presence as the design, facilitation, and direction of cognitive and social processes to support learning (Garrison \& Arbaugh, 2007; Garrison et al., 2000). Teaching presence has three components: (1) instructional design and organization (e.g., setting curriculum, designing methods, etc.); (2) facilitating discourse (e.g., setting course climate, acknowledging or reinforcing student contributions, etc.); and (3) direct instruction (e.g., summarizing the discussion, presenting content/ questions, etc.; Anderson et al., 2001). 


\section{Col Instructional Activities in Practice}

While the presences are important, they are of no use to instructors or instructional designers without guidance on how to foster them in online environments. For the purpose of this article, an instructional strategy refers to a method or activity used to help learners achieve a learning objective (Wolfe, 2010). Instructional strategies for each presence will be discussed in the next section of this review.

\section{Cognitive Presence and Course Design}

Instructional cognitive presence strategies include having students self-select topics they are curious about within the topic being taught, facilitating critical analyzation discussions (role-playing discussions), creating course rules to allow for an open environment for different perspectives, and encouraging students to share with each other resources related to the course topic (Richardson, Ice, \& Swan, 2009).

Improving cognitive presence in online courses can be done by focusing on the four phases of the PIM (triggering event, exploration, integration, and resolution; Garrison et al., 2000). However, what do these instructional activities look like? Triggering event items must provide learners with activities related to the inquiry process; exploration activities should focus on allowing students to brainstorm, discover, and openly discuss problems in an environment that supports such learning; and instructional activities developed around reflection and integration of ideas fall into theintegration stage (Richardson et al., 2010). According to Garrison, Cleveland-Innes, and Fung (2010) moving through the four domains of PIM, learners are "in an environment of reflection and discourse; analysis and synthesis" (p. 32) and thus reflection and the practice of staying engaged throughout the process enables movement toward the resolution phase.

\section{Social Presence and Course Design}

In a study conducted by Tu and McIsaac (2002), a link between the development of online social presence with course design was presented via trust building, "hand-holding" technical support, and promoting informal relationships; and, the authors argued that the dimension of social presence should be taken into consideration during course development. Course design elements used to support social presence (emotional affective) expressions, open communication, and group cohesion include personal profiles and photos, welcome messages, student profiles, limiting class size, structured learning activities, and activities in which students can incorporate feelings and personal experiences (Richardson et al., 2017).

When designing specifically for emotional (affective) expressions, activities should encourage initial and introductory content that helps develop trust and interactions among peers (Richardson et al., 2010). Creating course rules (i.e., netiquette), encouraging or requiring participation in discussions, and allowing opportunities for both peer-to-peer and peer-to-instructor connections (e.g., journals, blogs, and discussion) will allow for open lines of communication (Richardson et al., 2010; Stephens \& Roberts, 2017). For group cohesion, activities should include problem solving tasks, collaborative projects, and small group discussions that allow for the integration of community building (Richardson et al., 2010). 


\section{Teaching Presence and Course Design}

It is the instructor's role to create a narrative story or path through the course design and course content when using $\mathrm{CoI}$ as a foundation for effective course design (e.g., "This week we will be discussing," "I am going to divide you into groups," "I think Stephanie said it best"; Anderson et al., 2001). While many research studies focus on the role of teaching presence in online discussion forums, we must not exclude how an instructor's presence can be established in other aspects of the course (i.e., course announcements, weekly overviews, feedback to students or student groups, or design of assignment and course activities).

The instructional design and organization components are those items developed prior to the start of the course. By creating mini lectures (audio/video), embedding personal insight in course material, and providing scaffolding on how the course structure helps the learners, an instructor can plan for establishing a teaching presence (Richardson et al., 2010). Facilitating discourse (active teaching) calls for instructors to review student comments, move discussions forward, and check for accurate student understanding (Richardson et al., 2010). Lastly, direct instruction activities include giving detailed feedback to the learner as the content expert (Richardson et al., 2010).

\section{Designing for Community of Inquiry}

The previous section discussed different methods to implement CoI strategies into course design. Current CoI strategies are summarized in Table 1 for practitioners who wish to create an effective and meaningful online community. While online discussion can be invaluable for building online community, it can be ineffective if designed poorly. The same can be said of all strategies complied in Table 1. The table presented in this paper is needed in the field because the CoI framework does not provide specific instructional guidelines for implementation as a descriptive model. For ease of use, the author decided to align CoI instructional strategies with Sorensen and Baylen's (2009) online guidelines.

\section{Sorensen and Baylen's Format}

Sorensen and Baylen (2009) adapted Chickering and Gamson's (1987) widely cited "Seven Principles of Good Practice for Undergraduate Education," applying the guidelines to improve online student experiences. Newlin and Wang (2002) conducted a study implementing Chickering and Gamson's (1987) seven principles in online instruction; the study showed community collaboration was essential to the effective implementation of the principles. Ehrmann (2002), who has collaborated with Sorensen and Baylen, noted that Chickering and Gamson's (1987) seven principles, "seem equally important for all kinds of learners (and faculty) in all kinds of situations" (para. 1). However, in 2009, Sorensen and Baylen decided Chickering and Gamson's (1987) original seven principles were not enough to meet the needs of faculty who were new to teaching in online environments. Therefore, with help from faculty members across the country, the seven principles were adapted with adult learning theory in mind (Sorensen \& Baylen, 2009). Sorensen and Baylen's (2009) final principles, which parallel Chickering and Gamson's principles, include: 
1. Student-teacher contact, a principle focusing on the interaction between a student and instructor in an online environment;

2. Cooperation among students, a principle for effective teaching focusing on cooperation among students;

3. Activelearning, a principle emphasizing the importance of students to engage in meaningful learning activities and reflection on the process;

4. Prompt feedback, a principle focusing on giving guidance and feedback to ensure students are on the right track in terms of meeting course learning objectives;

5. Time on task, a principle concentrating on giving students assistance and guidance for managing their time in an online environment;

6. Communicate high expectations, a principle based on the theory that when instructors communicate to their students about high expectations for the course, students will aim to meet these expectations; and

7. Respect diverse ways of learning, a principle ensuring instructors are developing and implementing a wide variety of instructional strategies to meet the diverse population of students (p. 71).

\section{Summary of Instructional Activities for Col}

Given these principles, the author of this paper combined the frameworks (seven principles and CoI) to create a working document of $\mathrm{CoI}$ instructional strategies for practitioners and online instructors (Table 1). Literature selected for this study met the following criteria: must be an empirical study published in a peerreviewed journal, instructional strategy(ies) must confirm a positive impact or grouth on student learning or student perception of online community, is less than 20 years old, and did not include a specific technology in the testing (e.g., PowToon, Skype, MySpace). Articles with duplicate findings or instructional strategies were omitted and excluded from the table.

Table 1

Summary of Instructional Activities for CoI

\begin{tabular}{|c|c|c|}
\hline $\begin{array}{c}\text { Seven principles of } \\
\text { good practice for the } \\
\text { online environment }\end{array}$ & $\begin{array}{c}\text { CoI framework } \\
\text { presences }\end{array}$ & \\
\hline $\begin{array}{c}\text { Student-teacher } \\
\text { contact }\end{array}$ & Social presence & $\bullet \begin{array}{l}\text { Create a "Meet Your Classmates" section of your course where you and students } \\
\text { introduce yourselves to one another (Richardson, Ice, \& Swan, 2009). } \\
\text { Develop initial course activities (e.g., ice breakers) to encourage the development of } \\
\text { swift trust (Peacock \& Cowan, 2016; Richardson et al., 2009). } \\
\text { Model and encourage the use of verbal immediacy behaviors in interactions with } \\
\text { students (Richardson et al., 2009). }\end{array}$ \\
\hline
\end{tabular}




\begin{tabular}{|c|c|c|}
\hline & & 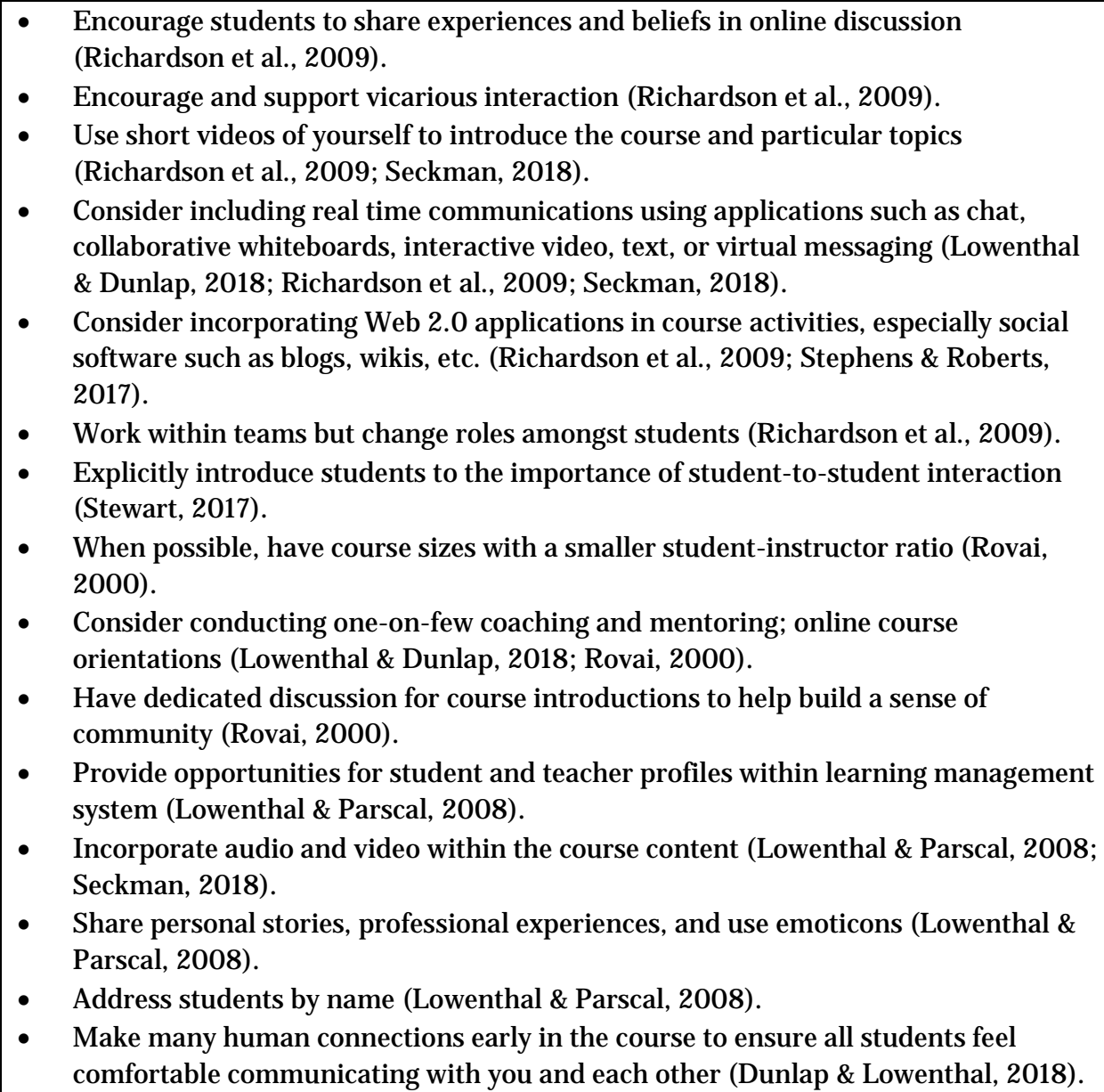 \\
\hline & $\begin{array}{l}\text { Cognitive } \\
\text { presence }\end{array}$ & $\begin{array}{l}\text { - Use content and process scaffolds to support discourse behaviors (Richardson et } \\
\text { al., 2009). } \\
\text { - } \quad \text { Reflect on student-teacher interactions (Redmond, 2014). }\end{array}$ \\
\hline & $\begin{array}{l}\text { Teaching } \\
\text { presence }\end{array}$ & 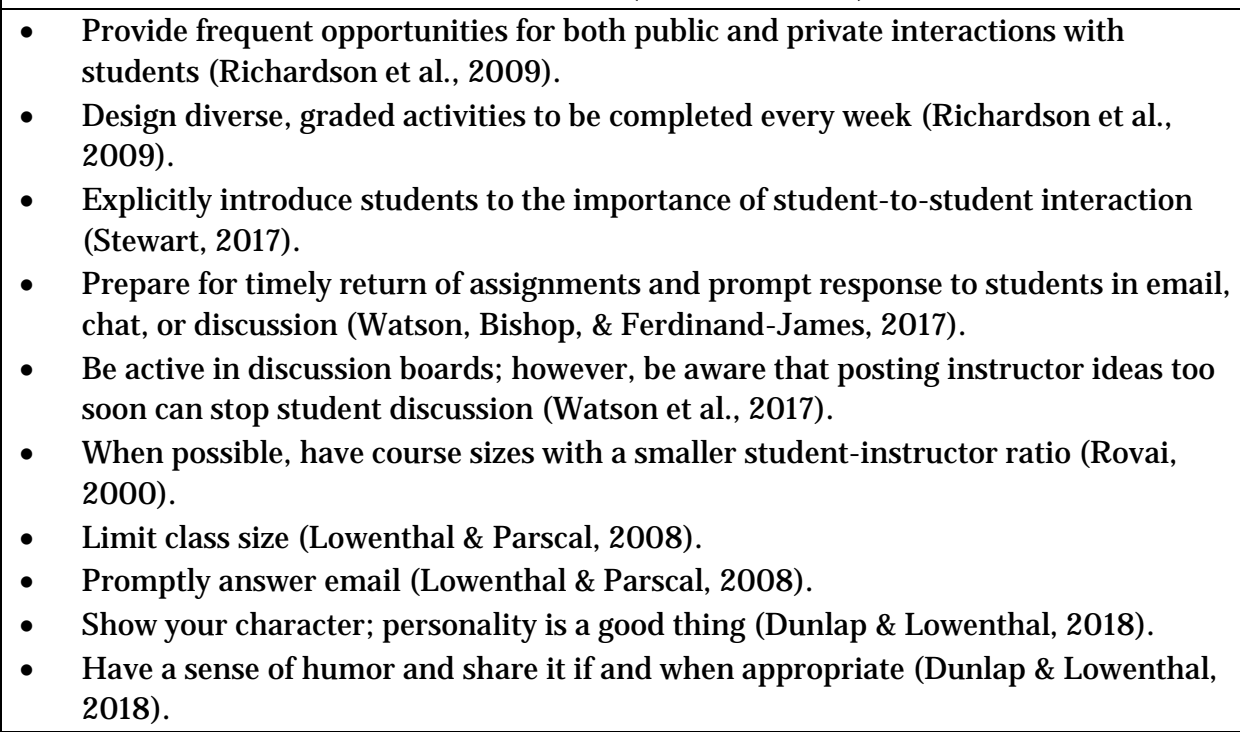 \\
\hline $\begin{array}{l}\text { Cooperation among } \\
\text { students }\end{array}$ & Social presence & $\begin{array}{l}\text { - Develop initial course activities (e.g., ice breakers) to encourage the development of } \\
\text { swift trust (Peacock \& Cowan, 2016; Richardson et al., 2009; Stephens \& Roberts, } \\
\text { 2017). }\end{array}$ \\
\hline
\end{tabular}




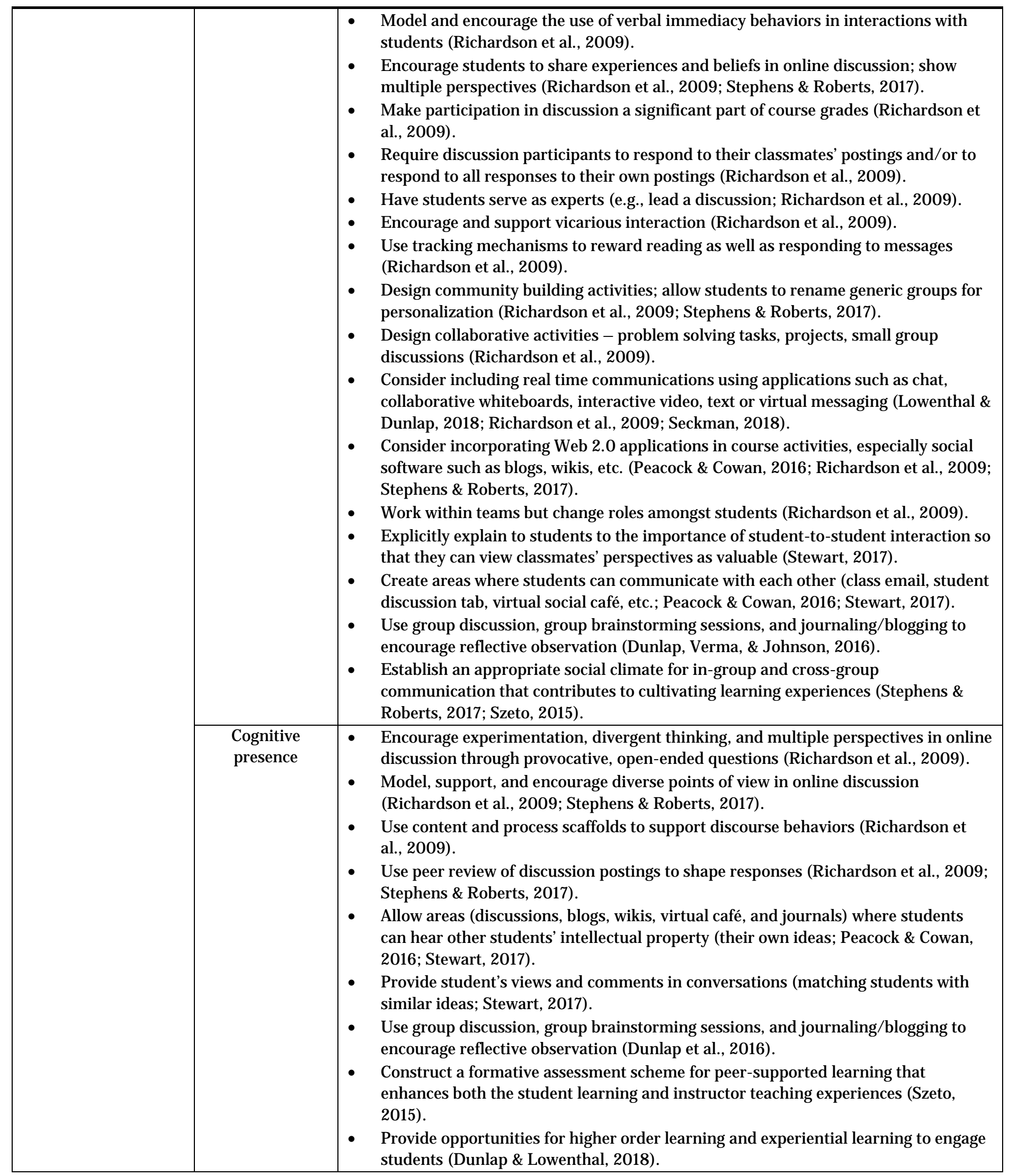




\begin{tabular}{|c|c|c|}
\hline & & - $\quad$ Reflect on group work or peer-supported learning experiences (Redmond, 2014). \\
\hline & $\begin{array}{l}\text { Teaching } \\
\text { presence }\end{array}$ & 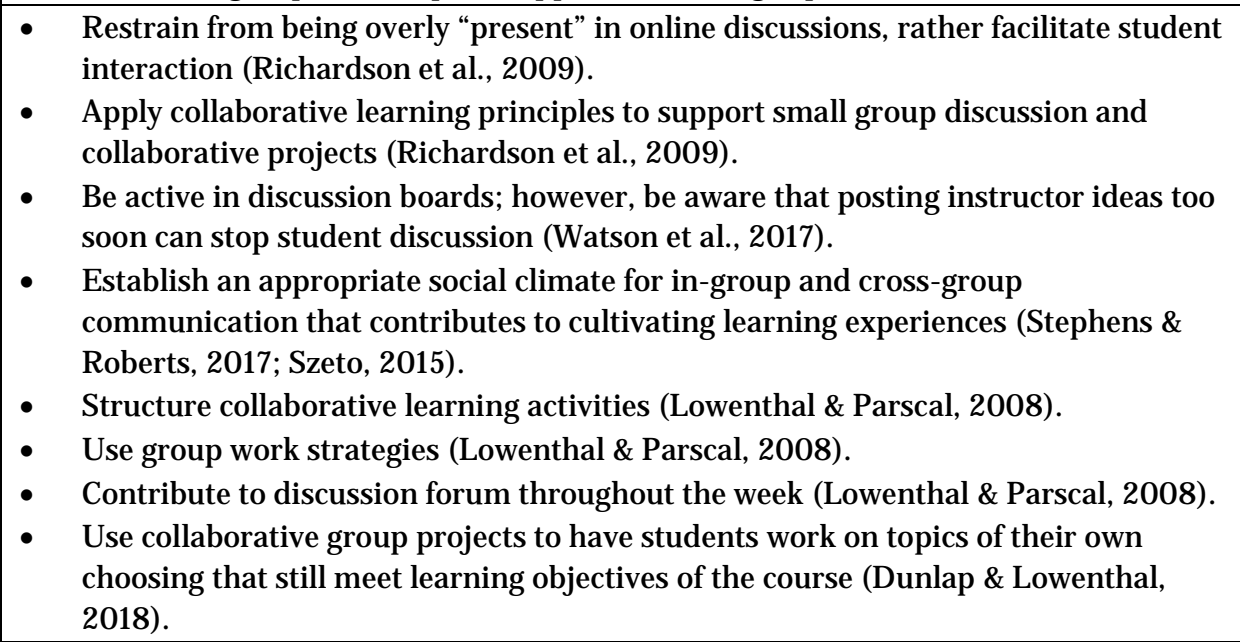 \\
\hline \multirow[t]{2}{*}{ Active learning } & Social presence & $\begin{array}{l}\text { - } \quad \text { Make participation in discussion a significant part of course grades (Richardson et } \\
\text { al., 2009). } \\
\text { - } \quad \text { Require discussion participants to respond to their classmates' postings and/ or to } \\
\text { respond to all responses to their own postings (Richardson et al., 2009). } \\
\text { - } \quad \text { Make students responsible for sustaining discussion threads (Richardson et al., } \\
\text { 2009). } \\
\text { - } \quad \text { Make students summarize discussion threads (Richardson et al., 2009). } \\
\text { - } \quad \text { Have students serve as experts (e.g., lead a discussion; Richardson et al., 2009). } \\
\text { - } \text { Require students to incorporate materials from the discussions in their } \\
\text { - } \quad \text { Ussignments (Richardson et al., 2009). } \\
\text { (Richardsong et al., 2009). } \\
\text { - J ournal or othervise interact with your students on an individual and personal } \\
\text { basis (Richardson et al., 2009). } \\
\text { - Consider incorporating Web 2.0 applications in course activities, especially social } \\
\text { software such as blogs, wikis, etc. (Peacock \& Cowan, 2016; Richardson et al., 2009; } \\
\text { Stephens \& Roberts, 2017). } \\
\text { Incorporate audio and video within the course content (Lowenthal \& Parscal, 2008; } \\
\text { - Seckman, 2018). } \\
\text { Let students post video responses, use apps like screencasting (Dunlap \& } \\
\text { Lowenthal, 2018; Seckman, 2018). }\end{array}$ \\
\hline & $\begin{array}{l}\text { Cognitive } \\
\text { presence }\end{array}$ & $\begin{array}{l}\text { - Identify big ideas you want students to take away from your course and develop } \\
\text { major course activities around their assessment (Richardson et al., 2009). } \\
\text { - Identify important knowledge, skills, and attitudes students should learn and } \\
\text { develop additional course activities around their assessment (Richardson et al., } \\
\text { 2009). } \\
\text { - } \\
\text { Provide multiple representations of the knowledge you want students to learn and } \\
\text { multiple activities for practicing desired skills (Richardson et al., 2009). } \\
\text { Encourage experimentation, divergent thinking, and multiple perspectives in online } \\
\text { discussion through provocative, open-ended questions (Richardson et al., 2009; } \\
\text { Stephens \& Roberts, 2017). } \\
\text { - Require discussion summaries that identify steps in the knowledge creation process } \\
\text { (Richardson et al., 2009). } \\
\text { Use peer review of discussion postings to shape responses (Richardson et al., 2009; } \\
\text { Stephens \& Roberts, 2017). }\end{array}$ \\
\hline
\end{tabular}




\begin{tabular}{|c|c|c|}
\hline & & $\begin{array}{l}\text { - Use online discussion and writing activities to support conceptual learning and } \\
\text { - } \quad \text { Use self-testing, practice assignments, simulations, and other interactive activities } \\
\text { to support skill development and convergent thinking (Richardson et al., 2009). } \\
\text { - Develop grading rubrics for discussion and course activities that reward desired } \\
\text { cognitive behaviors (Richardson et al., 2009). } \\
\text { - Develop general learning modules with opportunities for active learning, } \\
\text { assessment, and feedback that can be shared among courses and/ or accessed by } \\
\text { students for remediation or enrichment (Richardson et al., 2009). } \\
\text { - Developing discussions about students' intellectual property (their own ideas; } \\
\text { - Stewart, 2017). } \\
\text { Allow areas (discussions, blogs, wikis, virtual café, and journals) where students } \\
\text { can hear other students' intellectual property (their own ideas; Peacock \& Cowan, } \\
\text { 2016; Stewart, 2017). } \\
\text { - Involve students with video, case studies, labs, stories, simulations, and games } \\
\text { (Dunlap et al., 2016). } \\
\text { - Provide video/ audio lectures, have students complete readings, write position } \\
\text { papers, and model building (Dunlap et al., 2016; Seckman, 2018). } \\
\text { Provide students opportunities where they can complete projects and simulations, } \\
\text { engage in service learning and fieldwork (Dunlap et al., 2016). } \\
\text { Develop student- or teacher-led discussion groups, debates, projects, and } \\
\text { collaborative learning groups (Rovai, 2000). } \\
\text { Model higher-order thinking by frequently asking questions that probe students' } \\
\text { knowledge (Rovai, 2000). } \\
\text { Develop open-ended critical thinking discussion questions (Lowenthal \& Parscal, } \\
\text { 2008). } \\
\text { Incorporate reflective activities (Lowenthal \&Parscal, 2008). } \\
\text { Let students create and post materials, search out and post resources (Dunlap \& } \\
\text { Lowenthal, 2018). }\end{array}$ \\
\hline & $\begin{array}{l}\text { Teaching } \\
\text { presence }\end{array}$ & 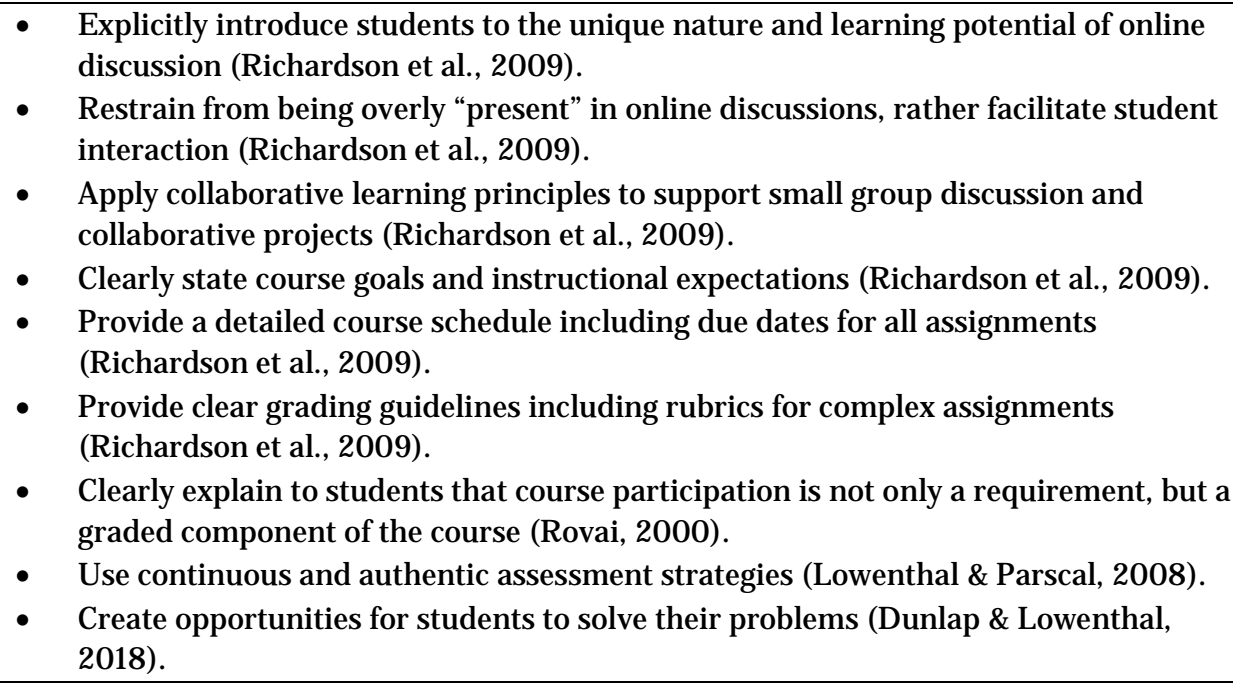 \\
\hline Prompt feedback & Social presence & $\begin{array}{l}\text { - Use audio/ video to embed feedback on assignments within them (Lowenthal \& } \\
\text { Dunlap, 2018; Richardson et al., 2009). } \\
\text { - Consider incorporating Web 2.0 applications in course activities, especially social } \\
\text { software such as blogs, wikis, etc. (Peacock \& Cowan, 2016; Richardson et al., 2009; } \\
\text { Stephens \& Roberts, 2017). } \\
\text { - Personalized feedback; one-to-one emails (Lowenthal \& Dunlap, 2018). }\end{array}$ \\
\hline
\end{tabular}




\begin{tabular}{|c|c|c|}
\hline & & $\begin{array}{l}\text { - Walk-through or how-to screencasts/videos regarding specific feedback (Lowenthal } \\
\text { - EDunlap, 2018). } \\
\text { - Use of phone calls (Lowenthal \& Dunlap, 2018). } \\
\text { - Use peer review for relationship building (Lowenthal \&Dunlap, 2018). }\end{array}$ \\
\hline & $\begin{array}{l}\text { Cognitive } \\
\text { presence }\end{array}$ & $\begin{array}{l}\text { - } \quad \text { Use peer review of discussion postings to shape responses (Richardson et al., 2009; } \\
\text { - } \quad \text { Dephens \& Roberts, 2017). } \\
\text { cognitive behaviors (Richardson et al., 2009) . } \\
\text { - } \quad \text { Provide frequent opportunities for testing and feedback (Richardson et al., 2009). } \\
\text { - } \quad \text { Automate testing and feedback when possible (Richardson et al., 2009). } \\
\text { - Develop general learning modules with opportunities for active learning, } \\
\text { assessment, and feedback that can be shared among courses and/ or accessed by } \\
\text { students for remediation or enrichment (Richardson et al., 2009). } \\
\text { - Use peer evaluations in the form of feedback (Rovai, 2000; Stephens \& Roberts, } \\
\text { 2017). } \\
\text { - Construct a formative assessment scheme for peer-supported learning that } \\
\text { enhances both the student learning and instructor teaching experiences (Stephens } \\
\text { \&Roberts, 2017; Szeto, 2015). } \\
\text { - Provide relevant individual and group feedback in a timely manner; feedback is } \\
\text { essential, and be specific in your feedback (Dunlap \& Lowenthal, 2018). }\end{array}$ \\
\hline & $\begin{array}{l}\text { Teaching } \\
\text { presence }\end{array}$ & 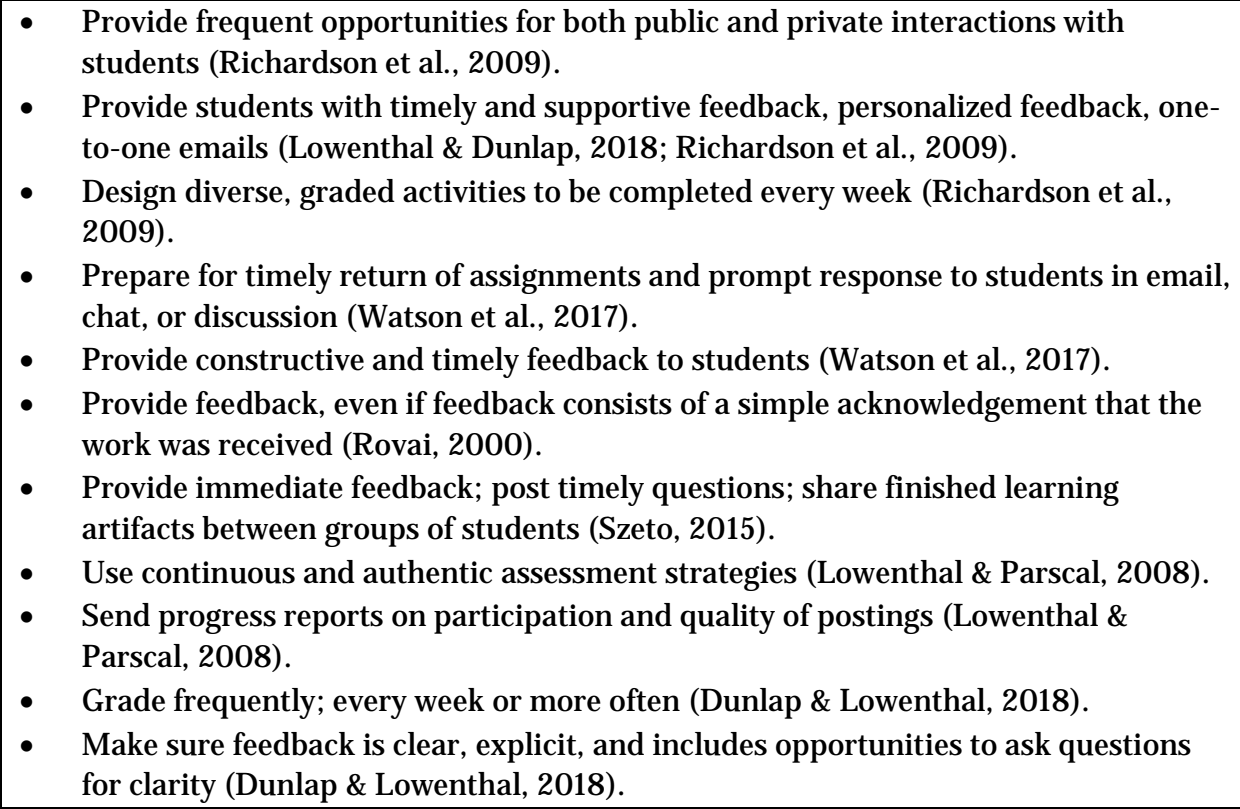 \\
\hline Time on task & Social presence & $\begin{array}{l}\text { - Explicitly introduce students to the unique nature and learning potential of online } \\
\text { discussion (Richardson et al., 2009). } \\
\text { - Consider incorporating Web 2.0 applications in course activities, especially social } \\
\text { software such as blogs, wikis, etc. (Peacock \& Cowan, 2016; Richardson et al., 2009; } \\
\text { Stephens \& Roberts, 2017). } \\
\text { - Instead of a text-based announcement, use a video walk through (Dunlap \& } \\
\text { Lowenthal, 2018; Seckman, 2018). } \\
\text { - Provide online orientation to the course, course video walk through (Lowenthal \& } \\
\text { Dunlap, 2018). }\end{array}$ \\
\hline & $\begin{array}{l}\text { Cognitive } \\
\text { presence }\end{array}$ & $\begin{array}{l}\text { Identify important knowledge, skills, and attitudes students should learn and } \\
\text { develop additional course activities around their assessment (Richardson et al., } \\
\text { 2009). }\end{array}$ \\
\hline
\end{tabular}




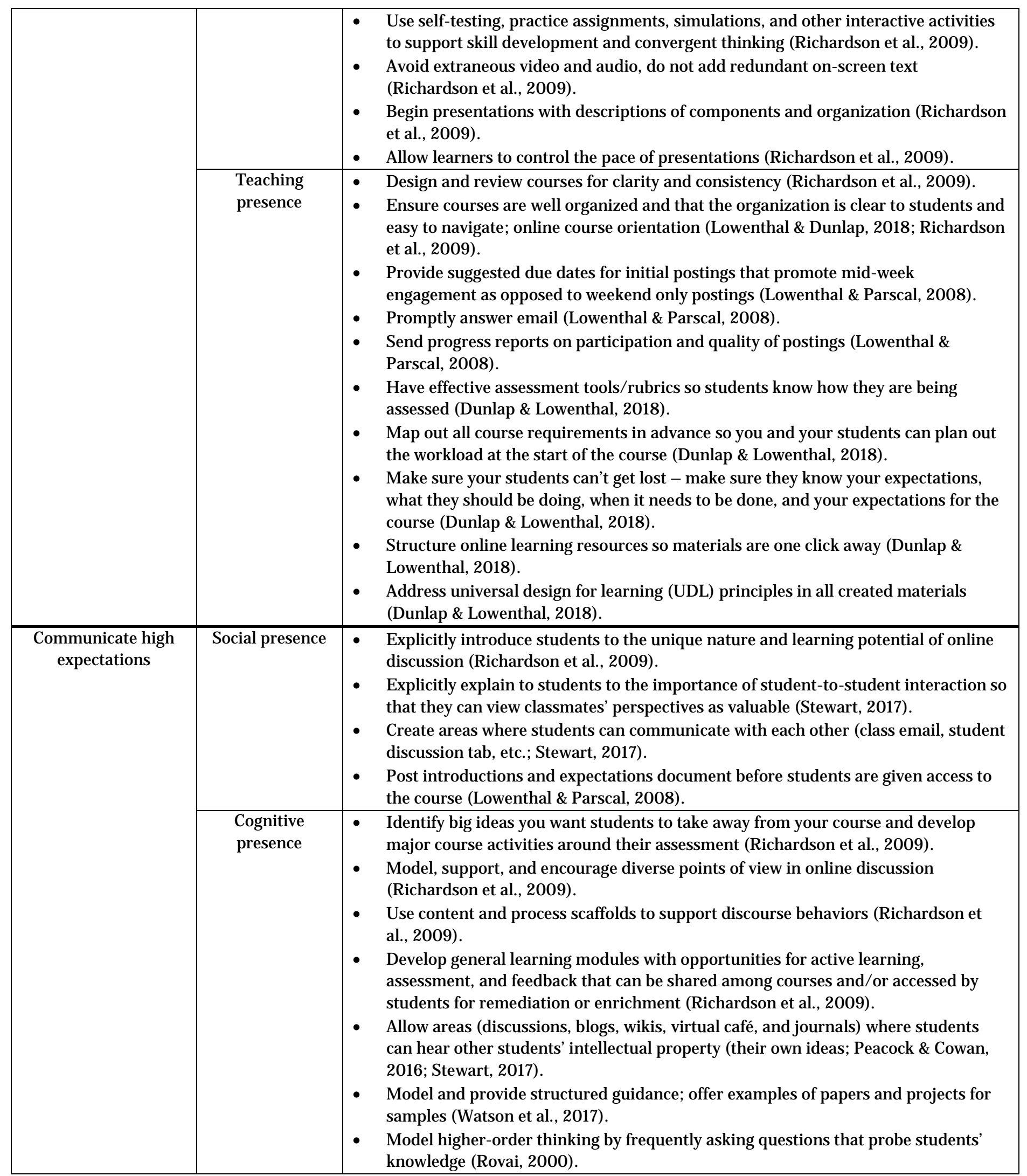




\begin{tabular}{|c|c|c|}
\hline & $\begin{array}{l}\text { Teaching } \\
\text { presence }\end{array}$ & 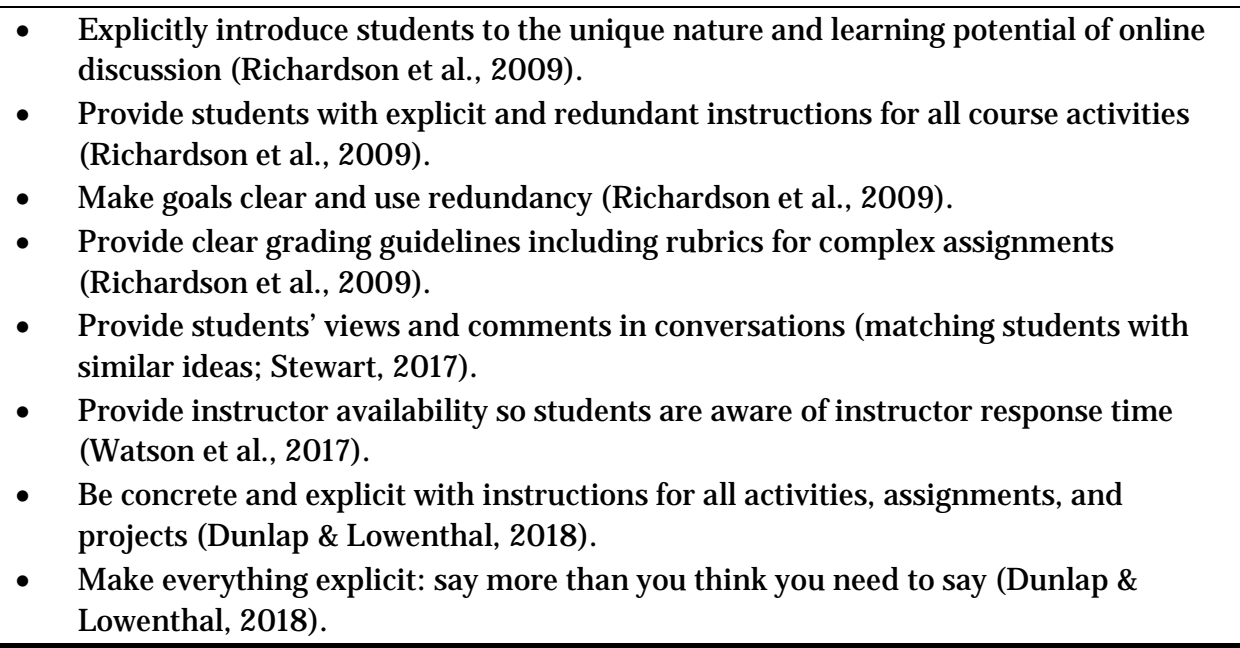 \\
\hline \multirow[t]{3}{*}{$\begin{array}{l}\text { Respect diverse ways } \\
\text { of learning }\end{array}$} & Social presence & $\begin{array}{l}\text { - } \quad \text { Establish rules of Netiquette for your course (Richardson et al., 2009; Stephens \& } \\
\text { Roberts, 2017). } \\
\text { - Encourage students to share experiences and beliefs in online discussion; allow for } \\
\text { multiple perspectives (Richardson et al., 2009; Stephens \& Roberts, 2017). } \\
\text { - } \quad \text { Have students serve as experts (e.g., lead a discussion; Richardson et al., 2009). } \\
\text { - } \text { sonsider incorporating Web 2.0 applications in course activities, especially social } \\
\text { Stephens \& Roberts, 2017). } \\
\text { - Use group discussion, group brainstorming sessions, and journaling/ blogging to } \\
\text { encourage reflective observation (Dunlap et al., 2016). }\end{array}$ \\
\hline & $\begin{array}{l}\text { Cognitive } \\
\text { presence }\end{array}$ & $\begin{array}{l}\text { - Provide multiple representations of the knowledge you want students to learn and } \\
\text { multiple activities for practicing desired skills (Richardson et al., 2009; Stephens \& } \\
\text { Roberts, 2017). } \\
\text { - Encourage experimentation, divergent thinking, and multiple perspectives in online } \\
\text { discussion through provocative, open-ended questions, authentic products } \\
\text { (Richardson et al., 2009; Stephens \& Roberts, 2017). } \\
\text { - Model, support, and encourage diverse points of view in online discussion } \\
\text { (Richardson et al., 2009; Stephens \& Roberts, 2017). } \\
\text { - Use self-testing, practice assignments, simulations, and other interactive activities } \\
\text { to support skill development and convergent thinking (Richardson et al., 2009). } \\
\text { - Develop general learning modules with opportunities for active learning, } \\
\text { assessment, and feedback that can be shared among courses and/ or accessed by } \\
\text { students for remediation or enrichment (Richardson et al., 2009). } \\
\text { - Present words in spoken form, use words and pictures simultaneously to explain } \\
\text { concepts (Richardson et al., 2009). } \\
\text { Use group discussion, group brainstorming sessions, and journaling/ blogging to } \\
\text { encourage reflective observation (Dunlap et al., 2016). } \\
\text { Involve students with video, case studies, labs, stories, simulations, and games } \\
\text { (Dunlap et al., 2016). } \\
\text { Provide video/ audio lectures, have students complete readings, write position } \\
\text { papers, and model building (Dunlap et al., 2016; Seckman, 2018). } \\
\text { Develop student- or teacher-led discussion groups, debates, projects, and } \\
\text { collaborative learning groups (Rovai, 2000). } \\
\text { Consider collaborative work where students can share alternative viewpoints with } \\
\text { each other (Rovai, 2000). }\end{array}$ \\
\hline & $\begin{array}{l}\text { Teaching } \\
\text { presence }\end{array}$ & $\begin{array}{l}\text { Provide frequent opportunities for both public and private interactions with } \\
\text { students (Richardson et al., 2009). }\end{array}$ \\
\hline
\end{tabular}




\begin{tabular}{|l|l|l|}
\hline & $\begin{array}{l}\text { Design courses for learner choice, flexibility, and control (Richardson et al., 2009). } \\
\text { - } \begin{array}{l}\text { Design learning experiences that address all learning preferences/ styles; authentic } \\
\text { products (Dunlap \& Lowenthal, 2018; Stephens \& Roberts, 2017). }\end{array} \\
\text { - Account for cultural differences (Dunlap \& Lowenthal, 2018). }\end{array}$ \\
\hline
\end{tabular}

\section{Conclusion}

\section{Summary}

Stemming from Dewey's emphasis on collaborative constructivism, Garrison et al. (2000) developed the $\mathrm{CoI}$ framework to build community in online environments. The CoI framework is the process of creating a meaningful learning experience through the development of three interdependent presences - social, cognitive, and teaching (Garrison et al., 2000). The CoI framework is currently becoming a concrete asset for creating online environments and thus meeting the issues online courses and programs are experiencing (e.g., the disconnect between students and their instructors, and students and their peers; Moskal, Dziuban, \& Hartman, 2013; Slagter van Tyron \& Bishop, 2009). The cognitive, social, and teaching presences work together in an overlapping, interdependent method to help students gain deep levels of community to support their individual learning (Szeto, 2015).

By reviewing the literature and studies on the CoI framework, there is a void of how to implement instructional strategies aligned with the CoI for practitioners. This paper presented an overview of online community and by orientating the CoI principles to Sorensen and Baylen's (2009) principles, a collection of instructional activities was presented to guide online practitioners in creating effective, engaging, and meaningful activities into course design and the facilitation process.

\section{Implications}

This review is significant to the field of instructional design and online education as it identifies evidencebased strategies and conceptualizes them into a working design document. This paper has implications for the field in terms of 1) informing online instructors and course developers about the importance of creating community in online environments; 2) providing an introduction and general review of the CoI framework; and 3) offering a design document to guide practitioners on instructional activities that best align with the CoI framework as well as the seven principles for best practices for the online environment.

\section{Limitations and Future Research}

For the summary of instructional activities (Table 1), the author provided an array of instructional strategies, as determined by the search criteria listed above, best suited for developing community. The list of instructional strategies is not all-inclusive; the author intentionally omitted duplicate instructional activities and excluded specific Web-tool activities as these constantly change (e.g., PowToon, Skype, MySpace). Additionally, a limitation of this review is that it focuses specifically on the original CoI framework and not on the literature addressing additional aspects (presences, influences), thereby potentially overlooking some potential strategies (e.g., tutor-facilitated CoI). Moreover, students may have individualized needs in terms of different presences; therefore, students may respond to instructional strategies differently (Lowenthal \&Dunlap, 2018). However, it is not without acknowledgement that further 
research should be conducted on the effectiveness of these instructional strategies as they align within the CoI framework and the seven principles work by Sorensen and Baylen (2009).

\section{References}

Anderson, T., Rourke, L., Garrison, D. R., \&Archer, W. (2001). Assessing teaching presence in a computer conference context. J ournal of Asynchronous Learning Networks, 5(2). Retrieved from http:// www.sloan-c.org/publications/jaln/v5n2/pdf/

Akyol, Z. \& Garrison, R. D. (2008). The development of a community of inquiry over time in an online course: Understanding the progression and integration of social, cognitive and teaching presence. J ournal of Asynchronous Learning Networks, 12(3), 3-22. doi: 10.24059/ olj.v12i3.66

Arbaugh, J . B. (2008). Does the community of inquiry framework predict outcomes in online MBA courses? International Review of Research in Open and Distance Learning, 9(2), 1-21. doi: https:// doi.org/ 10.19173/irrodl.v9i2.490

Dunlap, J . C. \&Lowenthal, P. R. (2018). Online educators' recommendations for teaching online: Crowdsourcing in action. Open Praxis, 10(1), 79-89. Retrieved from https:// openpraxis.org/index.php/ OpenPraxis/article/ view/ 721/421

Dunlap, J . C., Verma, G., \&J ohnson, H. L. (2016). Presence + experience: A framework for the purposeful design of presence in online courses. TechTrends, 60, 145-151. https:// doi.org/ 10.1007/ s11528016-0029-4

Ehrmann, S. (2002). New ideas, and additional reading [PDF file]. Retrieved from https:// teaching.uncc.edu/ sites/teaching.uncc.edu/files/media/ files/file/InstructionalTechnolog ies/SevenPrinciples-Technology.pdf

Garrison, D. R. (2007). Online community of inquiry review: Social, cognitive, and teaching presence issues. J ournal of Asynchronous Learning Networks, 11(1), 61-72. Retrieved from https:// files.eric.ed.gov/ fulltext/ EJ 842688.pdf

Garrison, D. R., Anderson, T., \&Archer, W. (2000). Critical inquiry in a text-based environment: Computer conferencing in higher education. The Internet and Higher Education, 2(2-3), 87-105. https:// doi.org/ 10.1016/ S1096-7516(00)00016-6

Garrison, D. R., \&Arbaugh, J . B. (2007). Researching the community of inquiry framework: Review, issues, and future directions. The Internet and Higher Education, 10(3), 157-172. https:// doi.org/ 10.1016/j.iheduc.2007.04.001 
Garrison, D. R., Cleveland-Innes, M., \& Fung, T. S. (2010). Exploring causal relationships among teaching, cognitive, and social presence: Student perceptions of the community of inquiry framework. Internet and Higher Education, 13(1-2), p. 31-36. doi:10.1016/j.iheduc.2009.10.002

Kozan, K., \& Caskurlu, S. (2018). On the Nth presence for the community of inquiry framework. Computers \&Education, 122, 104-118. https:/ / doi.org/ 10.1016/j.compedu.2018.03.010

Lowenthal, P., \& Dunlap, J . (2018). Investigating students' perceptions of instructional strategies to establish social presence. Distance Education, 39(3), 281-298. https:// doi.org/ 10.1080/01587919.2018.1476844

Lowenthal, D. A., \&Lowenthal, P. R. (2010, April). A mixed methods examination of instructor social presence in accelerated online courses. Paper presented at the annual meeting of the American Educational Research Association, Denver, CO. doi: 10.4018/978-1-4666-9582-5.ch006

Lowenthal, P. R., \& Parscal, T. (2008). Teaching presence online facilitates meaningful learning. The Learning Curve, 3(4), 1-2. Retrieved from http:// www.patricklowenthal.com/ publications/TeachingPresenceFacilitatesLearning.pdf

McMillan, D. W., \& Chavis, D. M. (1986). Sense of community: A definition and theory. J ournal of Community Psychology, 14, 6-23. doi: 10.1002/ 15206629(198601)14:1<6::AIDJ COP2290140103>3.0.CO

Moskal, P., Dziuban, C., \& Hartman, J . (2013). Blended learning: A dangerous idea? The Internet and Higher Education, 18, 15-23. https:// doi.org/ 10.1016/j.iheduc.2012.12.001

Newlin, M. H., \&Wang, A. Y. (2002). Integrating technology and pedagogy: Web instruction and seven principles of undergraduate education. Teaching of Psychology, 29(4), 325- 330. https:// doi.org/ 10.1207/ S15328023TOP2904_15

Peacock, S., \& Cowan, J . (2016). From presences to linked influences within communities of inquiry. International Review of Research in Open and Distance Learning, 17(5), 267-283. Retrieved from https:// eric.ed.gov/ ?id=EJ 1117447

Redmond, P. (2014). Reflection as an indicator of cognitive presence. E-Learning and Digital Media, 11(1), 46-58. https:// doi.org/ 10.2304/ elea.2014.11.1.46

Richardson, J .C., Arbaugh, J.C. Cleveland-Innes, M., Ice, P., Swan, K. and Garrison, D.R. (2010). Using the community of inquiry framework to inform effective instructional design. Paper presented at the 2010 AECT Research Symposium: Bloomington, IN, 2010. https:// doi.org/ 10.1007/ 978-14614-1785-9_7

Richardson, J . C., Ice, P., \& Swan, K. (2009). Tips and techniques for integrating social, teaching, \& cognitive presence into your courses. Poster session presented at the Conference on Distance Teaching \& Learning, Madison, WI. 
Richardson, J . C., Maeda, Y., Lv, J ., \&Caskurlu, S. (2017). Social presence in relation to students' satisfaction and learning in the online environment: A meta-analysis. Computers in Human Behavior, 71, 402-417. https:// doi.org/ 10.1016/j.chb.2017.02.001

Richardson, J . C., \& Swan, K. (2003). Examining social presence in online courses in relation to students' perceived learning and satisfaction. J ournal of Asynchronous Learning Networks, 7(1), 68-88. doi:10.1016/j.chb.2017.02.001

Rovai, A. P. (2000). Building and sustaining community in asynchronous learning networks. Internet and Higher Education, 3, 285- 297. https:/ / doi.org/ 10.1016/ S1096-7516(01)00037-9

Seckman, C. (2018). Impact of interactive video communication versus text-based feedback on teaching, social, and cognitive presence in online learning communities. Nurse Educator, 43(1), 18-22. doi: 10.1097/ NNE.0000000000000448

Slagter van Tryon, P. J ., \& Bishop, M. J . (2009). Theoretical foundations for enhancing social connectedness in online learning environments. Distance Education, 30(3), 291-315. https:// doi.org/ 10.1080/01587910903236312

Sorensen, C. K., \& Baylen, D. M. (2009). Learning online: Adapting the seven principles of good practice to a Web-based instructional environment. In A. Orellana, T. L. Hudgins, \& M. Samonson (Eds.), The perfect online course: Best practices for designing and teaching (pp. 69-86). Charlotte, NY: Information Age Publishing.

Stephens, G. E., \& Roberts, K. L. (2017). Facilitating collaboration in online groups. J ournal of Educators Online, 14(1), 1-16. Retrieved from https:// eric.ed.gov/ ?id=EJ 1133614

Stewart, M. K. (2017). Communities of inquiry: A heuristic for designing and assessing interactive learning activities in technology-mediated FYC. Computers and Composition, 45, 67-84. https:// doi.org/ 10.1016/j.compcom.2017.06.004

Swan, K., Garrison, D. R., \& Richardson, J . (2009). A constructivist approach to online learning: The community of inquiry framework. Information Technology and Constructivism in Higher Education: Progressive Learning Frameworks, 43-57. doi:10.4018/ 978-1-60566-654-9.ch004.

Swan, K., \& Ice, P. (2010). The Community of Inquiry Framework ten years later: Introduction to the special issue. The Internet and Higher Education, 13(1-2), 1-4. https:// doi.org/ 10.1016/j.iheduc.2009.11.003

Szeto, E. (2015). Community of inquiry as an instructional approach: What effects of teaching, social, and cognitive presences are there in blended synchronous learning and teaching? Computers and Education, 81, 191-201. doi: 10.1016/j.compedu.2014.10.015 
Tu, C. H., \& McIsaac, M. (2002). The relationship of social presence and interaction in online classes. American J ournal of Distance Education, 16(3), 131- 150. https:// doi.org/ 10.1207/ S15389286AJ DE1603_2

Wang, M., Laffey, J ., \& Poole, M. J . (2001). The construction of shared knowledge: In an Internet-based shared environment for expeditions (iExpeditions): A study of external factors implying knowledge construction. International J ournal of Educational Technology, 2(2). Retrieved from https:// www.learntechlib.org/p/92911/

Watson, F. F., Bishop, M. C., \& Ferdinand-J ames, D. (2017). Instructional strategies to help online students learn: Feedback from online students. TechTrends, 61, 420-427. https:// doi.org/ 10.1007/ s11528-017-0216-y

Wolfe, P. (2010). Brain matters: Translating research into classroom practice (2nd ed.). Alexandria, VA: ASCD Publications.

\section{Athabasca} University

$$
\text { (c) }
$$

